\title{
Mononuclear Cells in the Extraembryonic and Intraembryonic Coelom of the Mouse Embryo: A Semithin Light Microscopic Cytometry
}

\author{
Kazunobu SASAKI and George MatSumura \\ Department of Anatomy, Hokkaido University School of Medicine, Sapporo, Japan
}

Received March 14, 1989

\begin{abstract}
Summary. Mononuclear cells in the extraembryonic and intraembryonic spaces of mice were examined qualitatively and quantitatively by semithin light microscopy. At 9 and 10 days of gestation, the extraembryonic serous cavities contained a small number of mononuclear free cells. These cells had an elongated or kidney-shaped nucleus and the cell surface showed many villous projections. The cytoplasm occasionally contained small lucent vesicles but no phagocytic vacuoles. The average cell diameter was $8.4 \pm 0.9 \mu \mathrm{m}$ and $\mathrm{N}-\mathrm{C}$ ratio, $0.51 \pm 0.21$. Cell larger than $10 \mu \mathrm{m}$ in diameter constituted only $0.4 \%$ of the total. In vitelline vessels at 9 days, mononuclear cells bearing a close morphological resemblance to extraembryonic free cells were observed. At 12 days of gestation, extraembryonic and peritoneal cavities contained mature macrophages and a few small mononuclears which had the same morphological features as those in the extraembryonic coelom and vitelline vessels.
\end{abstract}

In adult animals, peritoneal cells consist of macrophages, monocytes, lymphocytes, neutrophils, eosinophils and mast cells (FELIX and DALTON, 1955; PADAWER and GORDON, 1956; MIMS, 1963; DAEMS and KOERTEN, 1978). In mice, during embryonic life, neither granulocytes nor lymphocytes are seen in the peritoneal cavity, and mast cells appear at the late gestational stage (SASAKI and MATSUMURA, 1988). In an 11-day mouse embryo, as reported earlier, the peritoneal cavity contains mononuclear free cells which, on histological sections, show evidence of phagocytosis, being classified as mature macrophages (SASAKI and MATSUMURA, 1988). In adult animals, phagocytic macrophages are known to belong to the Mononuclear Phagocyte System, MPS, and represent the most mature form of the system (VAN FURTH, 1982). Concerning the embryonic macrophages and their precursors before the start of hepatic hemopoiesis, however, little information is at present available. This study aims at a cytometrical observation of the mononuclear free cells in the embryonic cavities and yolk sac, using semithin plastic sections, and determination of the time of appearance and the morphology of macrophage precursors during the early embryonic life.

\section{MATERIAL AND METHODS}

Twenty-six embryos of dd-strain mice at $9,10,11,12$ and 13 days of gestation were used. An adult female was caged with a male overnight, and the next morning was taken as day 0 of pregnancy. Under chloroform anesthesia the abdomen was opened and the gravid uterus was immediately removed. Each segment of the uterus containing an embryo was placed in $4 \%$ paraformaldehyde- $5 \%$ glutaraldehyde in $0.1 \mathrm{M}$ cacodylate buffer for $3 \mathrm{~h}$ at room temperature. After dehydration with graded ethanols, the tissues were processed for embedding in methacrylate (New JB-4, Du Pont). At 9 and 10 days, serial sections including an embryo were cut at $1.0 \mu \mathrm{m}$ with glass knives on the microtome for semithin sections (Yamato, Japan). At 11 to 13 days of gestation, serial median sections of embryos were cut. Sections were

\footnotetext{
*This work was supported by a Grant-in Aid Scientific Research from the Japanese Ministry of Education, Science and
} Culture $(1988,1989)$. 


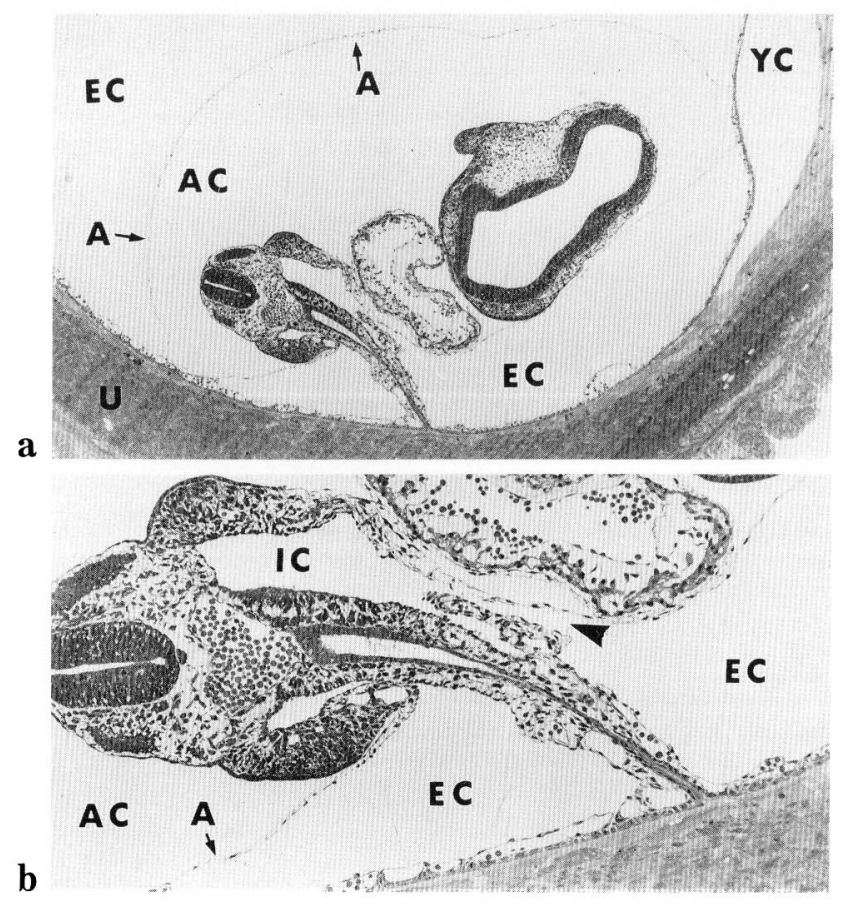

Fig. 1. Low power micrographs of a 9-day embryo. b May-Grünwald-Giemsa. a. Extraembryonic coelom $(E C)$ in the serous space between the amniotic cavity $(A C)$ and yolk cavity ( $Y C)$. A amnion, $U$ uterus. $\times 15$. b. Arrowhead indicates communication between the extraem. bryonic coelom $(E C)$ and intraembryonic coelom $(I C) . A$ amnion, $A C$ amniotic cavity. $\times 31$

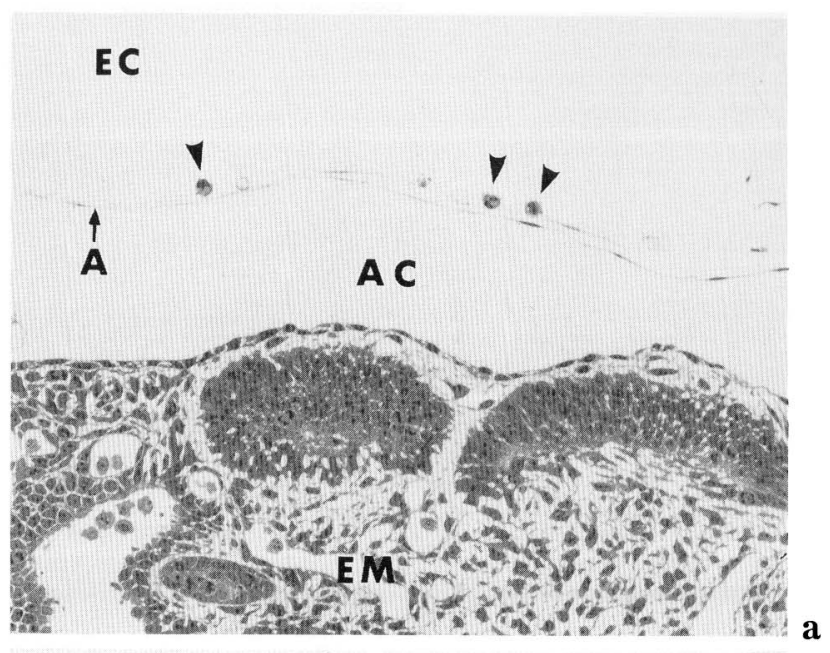

\section{E C}

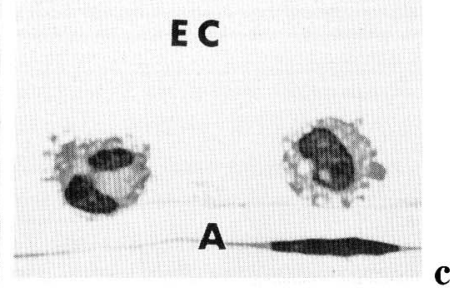

Fig. 2. Extraembryonic cells of a 10-day embryo. May. Grünwald-Giemsa. a. Three mononuclear cells (arrow heads) are seen in the extraembryonic coelom $(E C)$, located close to the amnion ( $A$ ). $A C$ amniotic cavity, $E M$ embryo. $\times 170$. b and c. Mononuclear cells in the extraembryonic coelom (EC) shown by the arrowheads in Fig. $2 \mathrm{a}$. Many projections are seen at the cell surface, and the cytoplasm contains small vesicles. $A$ amnion. $\times 1,100$

was obtained from the nucleus area and cell profile area. Twenty five mononuclear cells in vitelline vessels at 9 days, 50 cells in extraembryonic coelom at 10 days and 120 peritoneal cells at 12 days were measured for a scatter graph of cell size and N-C ratio. For cytometry, at least five embryos were used on each date.

\section{RESULTS}

\section{Mononuclear cells in extraembryonic coelom and vitelline vessels at 9 and 10 days of gestation}

In the endometrium of the gravid uterus, the mouse embryo was surrounded by three large serous cavities, i.e., the yolk cavity, amniotic cavity and extraembryonic coelom. The extraembryonic coelom, 

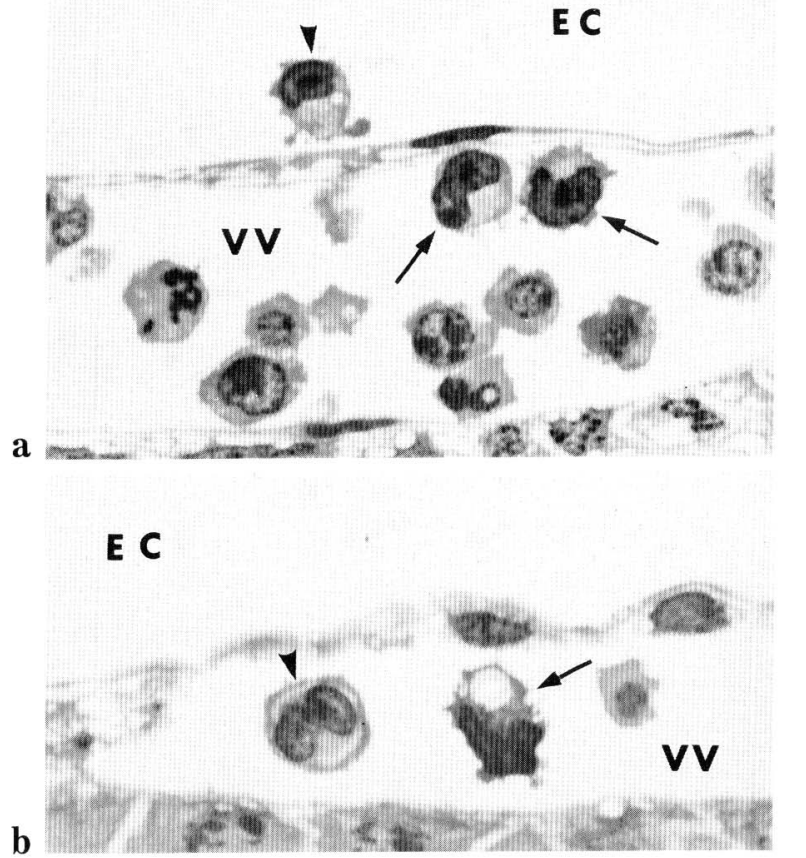

Fig. 3. Extraembryonic coelom $(E C)$ and vitelline vessel $(V V)$ of a 9-day embryo. May-Grüwald-Giemsa. a. A free mononuclear cell (arrowhead) is seen in the extraembryonic coelom. In the lumen of a vitelline vessel $(V V)$ two mononuclears (arrows) are shown, which morphologically resemble extraembryonic mononuclear cells. $\times 1,100$. b. A mononuclear cell (arrow) having a large vacuole in the cytoplasm and a megakaryopoietic cell (arrowhead) with a clear demarcation membrane around the nucleus are seen in a vitelline vessel $(V V) . \times 1,100$

exocoel, was located between the yolk and amniotic cavities (Fig. 1a) and was lined by mesothelial cells of the yolk sac and outer membrane of amnion. At 9 and 10 days of gestation, the exocoel was continuous with the body coelom (Fig. 1b). Free cells were not contained in the yolk cavity nor in the amniotic cavity. Small numbers of free mononuclear cells, however, existed in the extraembryonic coelom (Fig. 2a). In the exocoel, they were first recognized at day 9. They were scattered without any formation of nodules, being located close either to the mesothelial cells of the yolk sac or the outer membrane of amnion. Mononuclear cells then appeared slightly to increase in number.

Mononuclear cells in the exocoel at days 9 and 10 were roughly round or oval in profile (Figs. $2 b, c)$. They were characterized by the presence of many

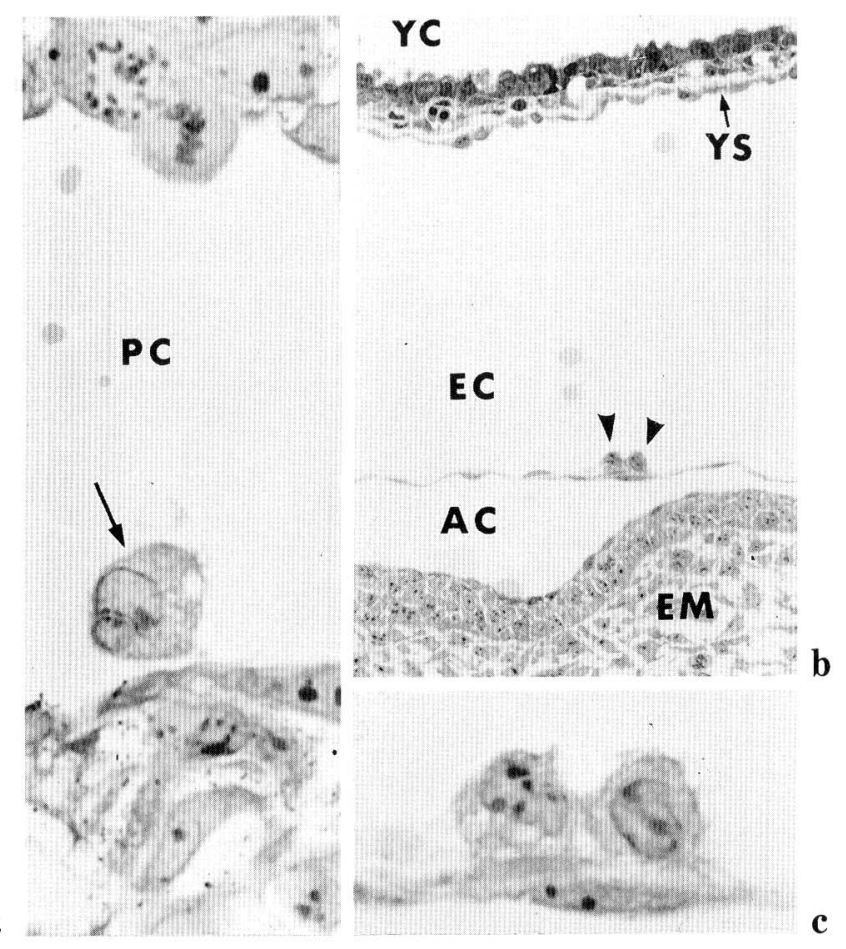

Fig. 4. Mononuclear cells in the peritoneal and extraembryonic cavities at 12 days of gestation. May-GrünwaldGiemsa. a. Mononuclear cell (arrow) in the peritoneal cavity $(P C)$. The large peritoneal cell has many clear vesicles varying in size within the cytoplasm. $\times 1,100$. b. Arrowheads indicate two large mononuclear cells in the extraembryonic coelom $(E C)$. $A C$ amniotic cavity, $E M$ embryo, $Y C$ yolk cavity, $Y S$ yolk sac. $\times 170$. c. Two extraembryonic cells, enlarged from Fig. 4b, are basically similar in cytoplasmic features to peritoneal free cells. $\times 1,100$

villous extensions which, varying widely in shape, length and diameter, were 0.7 to $2.0 \mu \mathrm{m}$ long with thread-, finger- or drumstick-like profiles. The nucleus generally had an eccentric position and was usually elongated, its long axis $4-9 \mu \mathrm{m}$ and short axis 3-5 $\mu \mathrm{m}$, or kidney-shaped, and occasionally deeply indented. The heterochromatin was disposed along the circumference of the nuclear envelope, and the nucleolus was inconspicuous. A small round or oval lightly stained area was seen in the cytoplasm on the concave side of the nucleus. The cytoplasm occasionally contained small lucent vesicles but no phagocytic vacuoles; azurophilic granules were inconspicuous.

The distribution of cell diameters and N-C ratio of exocoelomic mononuclear cells at day 10 are shown in the scatter graph of Figure $5 \mathrm{~b}$. The cell diameters ranged from 6.5 to $10.5 \mu \mathrm{m}$, being $8.4 \pm 0.9 \mu \mathrm{m}$ on the 

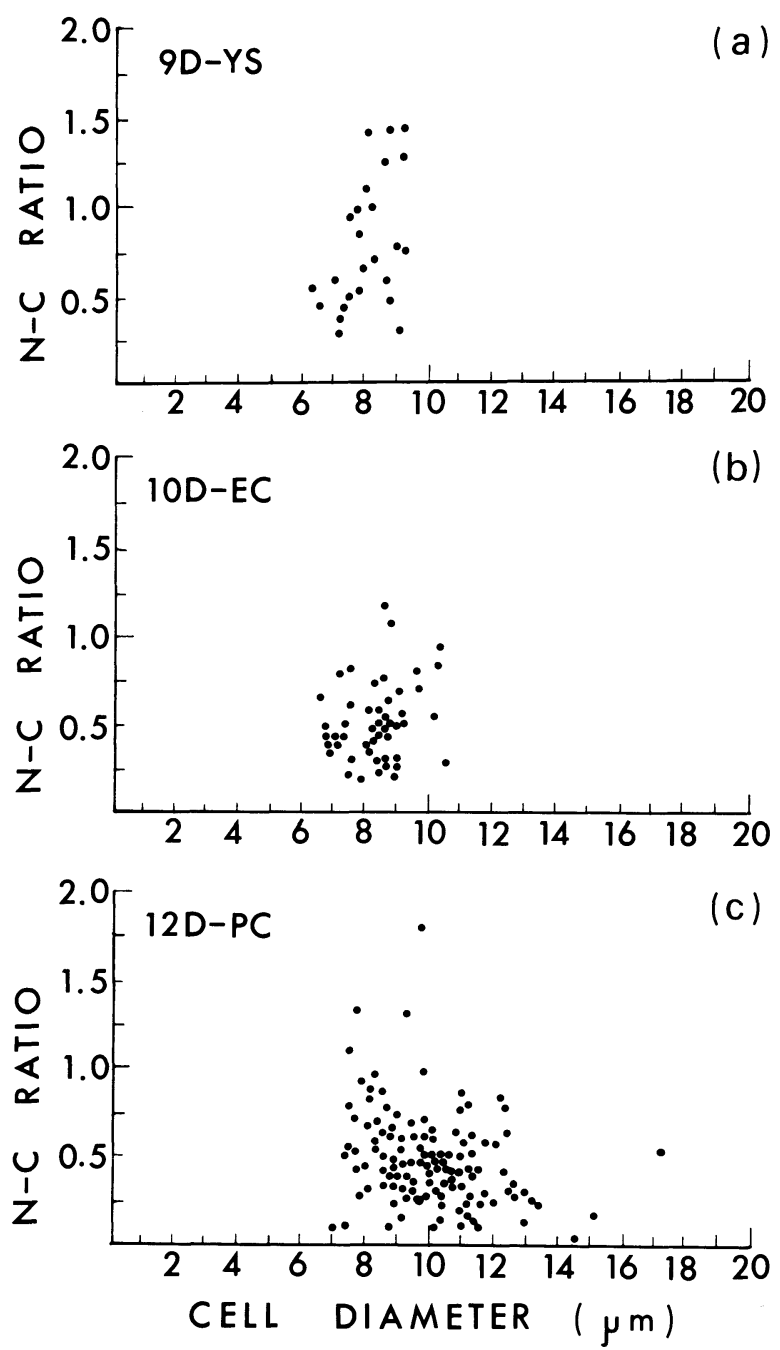

Fig. 5. Relationship between cell diameters and N-C ratios of mononuclear cells in 9-day yolk sac vitelline vessels (a), in 10-day extraembryonic coeloms (b) and in 12-day peritoneal cavities (c).

average. Mononuclear cells larger than $10 \mu \mathrm{m}$ in diameter constituted only $0.4 \%$ of the total. The average N-C ratio was $0.51 \pm 0.21$, and the cells with a ratio lower than 0.6 accounted for $72 \%$. Mononuclear cells with a large N-C ratio higher than 1.0 were very few.

At 9 days, when mononuclears first appeared in the exocoel, the embryonic circulation contained mononuclear cells which were similar in morphological features to extraembryonic ones (Fig. 3a). At 9 and 10 days, the vast majority of yolk sac hemopoietic cells in vitelline vessels were primitive erythroblasts. These erythroblasts had a round nucleus and were smoothly contoured in cell outline. Neither vacuoles nor lucent vesicles were seen in the cytoplasm. In addition to erythroids, a very small number of megakaryopoietic cells with clearly demarcated membranes around the nucleus were found (Fig. 3b). Mononuclear cells bearing a close morphological resemblance to extraembryonic free cells were seen only in very small numbers. Yolk sac mononuclear cells were round in contour, and exhibited many short cytoplasmic projections on the cell surface. The nucleus was eccentric in position and were oval or kidney-shaped in configuration. A cytocentrum appeared as a small clear area in the nuclear indentation. The cytoplasm occasionally contained one or more large lucent vacuoles (Fig. $3 \mathrm{~b}$ ).

The yolk sac mononuclear cells at 9 days varied between 6 and $9 \mu \mathrm{m}$ in cell diameter, being $8.0 \pm 0.8$ $\mu \mathrm{m}$ on the average (Fig. 5a). The cell diameter was similar in distribution pattern to that in the extraembryonic coelom (Fig. 5b). Cells larger than $9 \mu \mathrm{m}$ in cell diameter comprised approximately $25 \%$ of the total. The $\mathrm{N}-\mathrm{C}$ ratio ranged from 0.25 to 1.5 with a mean of $0.79 \pm 0.36$. Mononuclear cells higher than 1.0 in $\mathrm{N}-\mathrm{C}$ ratio occupied $28 \%$, and cells lower than 0.6 in $\mathrm{N}-\mathrm{C}$ ratio accounted for $44 \%$.

\section{Mononuclear cells in intraembryonic and extra- embryonic coelom at 11-13 days of gestation}

Between 10 and 12 days, the peritoneal cavity became separated from the extraembryonic coelom and both cavities contained mononuclear free cells in small numbers. In the peritoneal cavity, large mononuclear cells classifiable as macrophages appeared and increased in number (Fig. 4a). They were round or oval with many filopodia extending from the cell surface. The oval or kidney-shaped nucleus took an eccentric position. The cytoplasm frequently contained many lucent vacuoles, vesicles and occasional large phagosomes. In the exocoel appeared large free mononuclear cells, which were similar in morphological features to mature macrophages (Figs. 4b, c).

Correlation between the cell diameter and N-C ratio of peritoneal cells at day 12 is shown in the scatter graph of Figure $5 \mathrm{c}$. The cell diameter ranged from 7 to $17 \mu \mathrm{m}$ with a mean of $9.9 \pm 1.6 \mu \mathrm{m}$. Cells larger than $10 \mu \mathrm{m}$ in diameter comprised $52.5 \%$ of the total. The $\mathrm{N}-\mathrm{C}$ ratio ranged from 0.1 to 1.78 and $0.54 \pm 0.31$ on the average. Cells lower than 0.6 in N-C ratio constituted $69 \%$, and cells higher than 1.0 in the ratio made up $5 \%$. 


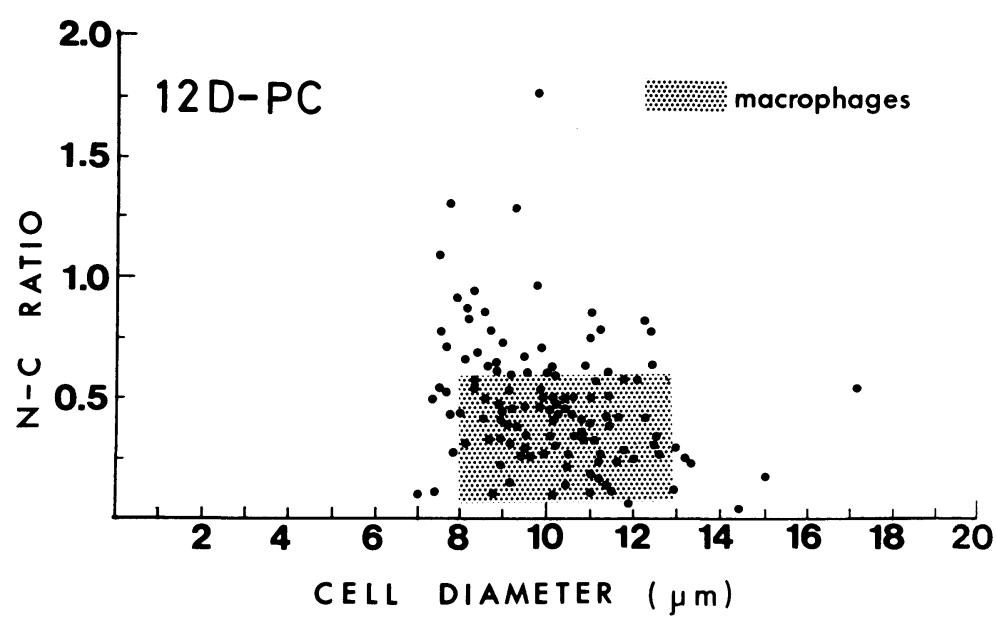

Fig. 6. Comparison between peritoneal cells in 12-day embryos and peritoneal macrophages from the adult mouse.

\section{DISCUSSION}

The present study shows that the mononuclear free cells first appear in the embryonic cavity at the 9th day of gestation prior to the liver hemopoiesis. They are smaller in cell size and higher in N-C ratio, compared with peritoneal mononuclears at 12 days of gestation.

It is now generally accepted that macrophages in adult animals originate from progenitor cells located in the bone marrow (overview in VAN FURTH, 1982; JOHNSTON and ZUCKER-FRANKLIN, 1988). In the course of macrophage differentiation, the cell size characteristically changes. In mice, promonocytes in the bone marrow measure $14-20 \mu \mathrm{m}$ in cell diameter; monocytes in the bone marrow and peripheral blood, 11-14 $\mu \mathrm{m}$; and macrophages in the connective tissue, 10-25 $\mu \mathrm{m}$ (FEDORKO and HIRSCH, 1970; VAN FURTH et al., 1980). As for the N-C ratio, the MPS cells undergo a gradual decrease during the first stage of differentiation. The ratio is higher than 1 for promonocytes, around 1 for monocytes, and smaller than 1 for macrophages (FEDORKO and HIRSCH, 1970; VAN FURTH et al., 1980). Similar results were obtained with ultrathin electron microscopy (VAN DER MEER et al., 1980). Cytometrical analyses of peritoneal cells in adult mice have indicated that peritoneal macrophages are 8-13 $\mu \mathrm{m}$ in cell diameter (WILliams and MAYHEW, 1973; ABE et al., 1979). The cell size and N-C ratio are considered to be useful parameters for cell differentiation of the MPS. Taking the cell diameter and
$\mathrm{N}-\mathrm{C}$ ratio together into consideration, peritoneal macrophages are contained in a dotted rectangle in Figure 6 . The majority of the peritoneal cells at 12 days could be classified into macrophages morphologically as well as cytometrically. In the peritoneal cavity, in addition, there exist mononuclears higher in $\mathrm{N}-\mathrm{C}$ ratio than macrophages.

Yolk sac vitelline vessels at early gestational stages contain hemopoietic cells, which are mostly erythroids (HAAR and ACKERMAN, 1971; SASAKI and KENDALL, 1985); megakaryopoietic cells are mixed in very small number among the primitive erythroblasts (MATSUmuRA and SASAKI, 1988). FukUda (1973) reported that phagocytic macrophages were present in the human yolk sac before the start of hepatic hemopoiesis. Like extraembryonic free cells, cytoplasmic projections are visible at the cell surface of yolk sac mononuclears. As shown in the results, mononuclear cells having large vacuoles in the cytoplasm are observed in small numbers within the vitelline vessels at 9 days of gestation. Although yolk sac mononuclear cells, $6-9 \mu \mathrm{m}$ in cell diameter, are small in cell size, they have a generally high N-C ratio, ranging from 0.4 to 1.4 . It is likely, therefore, that yolk sac mononuclear cells higher than 1.0 in $\mathrm{N}-\mathrm{C}$ ratio are the earliest recognizable precursors of mature macrophages in embryonic cavities during the early intrauterine life of the mouse.

Acknowledgments. The authors would like to thank Professor Emeritus Dr. Takashi ITo for reviewing this manuscript. 


\section{REFERENCES}

ABE, K., S. Honma and T. Ito: Peritoneal cells in mice: quantitative and qualitative cell morphology. Amer. J. Anat. 156: 37-50 (1979).

Daems, W. Th. and H. K. Koerten: The effects of various stimuli on the cellular composition of peritoneal exudates in the mouse. Cell Tiss. Res. 190: 47-60 (1978).

Fedorko, M. E. and J. G. Hirsch: Structure of monocytes and macrophages. Seminars Hematol. $7:$ 109-124 (1970).

Felix, M. D. and A. J. Dalton: A phase-contrast microscope study of free cells native to the peritoneal fluid of DBA/2 mice. J. Nat. Cancer Inst. 16: 415-445 (1955).

FUkUdA, T.: Fetal hemopoiesis. I. Electron microscopic studies on human yolk sac hemopoiesis. Virchows Arch. B Zellpathol. 14: 197-213 (1973).

HaAR, J. L. and A. Ackerman: A phase and electron microscopic study of vasculogenesis and erythropoiesis in the yolk sac of the mouse. Anat. Rec. 170: 199-224 (1971).

Johnston, R. B., Jr. and D. Zucker-Franklin: The mononuclear phagocyte system. Monocytes and macrophages. In: (ed. by) D. ZuCKer-FrAnkLIN, M. F. Greaves, C. E. Grossi and A. M. Marmont: Atlas of blood cells. Function and pathology. Edi. Ermes S.R.L., Milano, 1988 (p. 321-357).

Matsumura, G. and K. Sasaki: The ultrastructure of megakaryopoietic cells of the yolk sac and liver in mouse embryo. Anat. Rec. 222: 164-169 (1988).

Mims, C. A.: The peritoneal macrophages of mice. Brit. J. Exp. Pathol. 45: 37-43 (1963).

Padawer, J. and A. S. Gordon: Cellular elements in the peritoneal fluid of some mammals. Anat. Rec. 124: 209222 (1956).

SASAKI, K. and M. D. Kendall: The morphology of the haemopoietic cells of the yolk sac in mice with particular reference to nucleolar changes. J. Anat. 140:279-295 (1985).
SaSaki, K. and G. Matsumura: A semithin light microscopic study of peritoneal cells of the mouse embryo. Arch. Histol. Cytol. 51: 277-283 (1988).

Van Der Meer, J. W. M., J. S. Van De Gevel, M. M. C. Diesselhoff-Den Dulk, R. H. J. Beelen and R. VAN FURTH: Long-term cultures of murine bone marrow mononuclear phagocytes. In: (ed. by) R. VAN FURTH: Mononuclear phagocytes, Part I. Martinus Nijhoff Publ., Hague, 1980 (p. 343-361).

Van Furth, R.: Current view on the mononuclear phagocyte system. Immunobiology 161: 178-185 (1982).

Van Furth, R., M. M. C. Diesselhoff-Den Dulk, J. A. Raeburn, Van Zwet, R. Crofton and A. B. Van Oud ALBLAS: Characteristics, origin and kinetics of human and murine mononuclear phagocytes. In: (ed. by) R. VAN FURTH: Mononuclear phagocytes, Part I. Martinus Nijhoff Publ., Hague, 1980 (p. 279-298).

Williams, M. A. and T. M. MaYhew: Quantitative microscopical studies of the mouse peritoneal macrophage following stimulation in vivo. Z. Zellforsch. 140: 187-202 (1973).

\author{
Dr. Kazunobu SASAKI \\ Department of Anatomy \\ Hokkaido University School of Medicine \\ Kita-15, Nishi-7, Kita-ku \\ Sapporo, 060 Japan \\ 佐々木 和 信 \\ 060 札幌市北区北 15 条西 7 丁目 \\ 北海道大学医学部 \\ 解剖学教室
}

